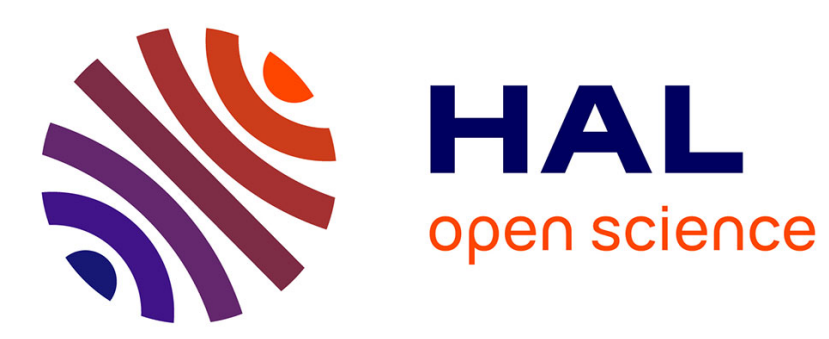

\title{
Bank Lending and Income Inequality: Evidence from Indonesia
}

Putra Pamungkas, Clovis Rugemintwari, Amine Tarazi, Irwan Trinugroho

\section{To cite this version:}

Putra Pamungkas, Clovis Rugemintwari, Amine Tarazi, Irwan Trinugroho. Bank Lending and Income Inequality: Evidence from Indonesia. 2016. hal-01251500

\section{HAL Id: hal-01251500 \\ https://hal-unilim.archives-ouvertes.fr/hal-01251500}

Preprint submitted on 6 Jan 2016

HAL is a multi-disciplinary open access archive for the deposit and dissemination of scientific research documents, whether they are published or not. The documents may come from teaching and research institutions in France or abroad, or from public or private research centers.
L'archive ouverte pluridisciplinaire HAL, est destinée au dépôt et à la diffusion de documents scientifiques de niveau recherche, publiés ou non, émanant des établissements d'enseignement et de recherche français ou étrangers, des laboratoires publics ou privés. 


\title{
Bank Lending and Income Inequality: Evidence from Indonesia
}

\author{
Putra Pamungkas ${ }^{\mathrm{a}}$, Clovis Rugemintwari ${ }^{\mathrm{a}}$, Amine Tarazi $^{\mathrm{a}}$, Irwan Trinugroho ${ }^{\mathrm{b}}$ \\ ${ }^{a}$ Université de Limoges, LAPE, 5 rue Félix Eboué, 87031 Limoges Cedex, France \\ ${ }^{b}$ Faculty of Economics and Business, Universitas Sebelas Maret, Jl. Ir. Sutami 36A, Surakarta \\ 57126, Indonesia
}

\begin{abstract}
This paper investigates the relationship between financial development and income inequality by using a broad range of loan categories as proxies for financial development. Our unique data set allows us to identify loans to micro, small and medium-sized enterprises (MSMEs). It also allows us to distinguish business loans and consumer loans. Using panel data for 33 provinces in Indonesia during the 2007-2013 period, we find that lending to MSMEs reduces income inequality while businesses loans, either for working capital or investment purposes, but also consumer loans increase income inequality. Our results indicate that boosting loans to micro, small, and mediumsized enterprises could significantly contribute to reduce income inequality.
\end{abstract}

Keywords: Income Inequality, Gini Index, Bank Lending, Indonesia

JEL Classification: G21, D3, 015, P36, R11 


\section{Introduction}

In the early 1980s, Indonesia experienced difficult economic conditions pushing bank regulators to issue a deregulation package to boost the economy. Financial deregulation which was part of the package has led to a significant increase in credit to the private sector. The Indonesian financial system is considered as a bank-based financial system in which banks play a more important role in funding the economy than capital markets ${ }^{1}$. In such a system bank lending is essential to promote economic growth.

Apart from promoting economic growth ${ }^{2}$, the question is whether financial development can be an instrument to reduce income inequality. Theoretical, as well as empirical studies regarding the finance - inequality nexus, provide mixed evidence. While some studies show that financial development contributes to reduce income inequality, others argue that finance only benefits for the rich due to lack of access to finance for the poor.

In their theoretical contribution, Greenwood and Javanovic (1990) find an inverted U-shaped relationship between financial development and income inequality. In the early stages, financial development increases income inequality while alleviating it later on. In their setting, financial development is only beneficial for the rich in the first stage because of high financial intermediation cost. Further on with higher economic growth, poverty, as well as income inequality, fall down. By contrast, Banerjee and Newman (1993) and Galor and Zeira (1993) argue that financial development has a negative impact on income inequality. Long-run convergence in income levels will not necessarily occur in economies with capital market imperfections and indivisibilities in human or physical capital investment (Clarke et al. 2003). Empirical studies also provide mixed evidence although most papers highlight the absence of any threshold effect. Liang (2006), Clarke et al. (2003) and $\mathrm{Li}$ et al. (1998) find a linear relationship on the nexus between finance and inequality. Clarke et al. (2003) specifically also find no evidence of a possible inverted U-shaped relationship between financial development and income inequality.

By using various measures most of the empirical studies on the finance-inequality nexus find that financial development has a negative impact on income inequality. Beck et al. (2007) and Clarke et al. (2006) use private the ratio of credit to GDP to measure financial development; Gimet and Lagoarde-Segot (2011) capture financial development by using a banking sector indicator (interest spread) and a capital market indicator (market capitalization of listed companies to GDP ratio). Kappel (2010) uses private credit channeled by deposit money banks and other financial institution as well as stock market capitalization to GDP to measure financial development. Private credit is a comparatively broad measure of credit issuing intermediaries since it also includes the loans provided financial intermediaries that are not deposit money banks (Beck et al., 2007).

In the present paper, we break down bank loans into three types based on lending purposes to investigate the effect of financial development on income inequality. In this regard, we contribute to the existing finance-inequality nexus literature by providing evidence on which type of loans might possibly reduce income inequality. To the best of our knowledge, this is the first paper to address this issue. We use detailed data of three types of loan across 33 provinces in Indonesia which are business loans, consumer loans,

\footnotetext{
${ }^{1}$ The capital market is still relatively under developed as shown by the number of publicly-traded firms and low transaction volumes (Trinugroho et al., 2014).

${ }^{2}$ See Levine (2005) and Beck et al. (2000) for a detailed review on the finance - growth nexus literature.
} 
and loans to micro, small medium and enterprises scaled by province population. We also decompose business loans into loans to working capital and investment. We define business loans as loans to industries or large firms, consumer loans as loans to individuals or households, and loans to small and medium-sized enterprises are loans to small-sized businesses. Arguably, loans to micro, small and medium-sized enterprises could lower the level of income inequality as such loans are mostly granted to lower middle society.

Our results show that bank loans to micro, small and medium-sized enterprise contribute to reduce income inequality, whereas bank loans to investment and working capital as well as consumer loan exacerbates inequality.

\section{Data, Sample, and Measurement.}

To investigate the relationship between different types of bank lending and income inequality, we use provincial-level panel data of 33 provinces of Indonesia from 2007 to 2013. All data on bank lending at provincial level are retrieved from Indonesian Banking Statistics provided by Bank Indonesia while the Gini Index and macroeconomic data at the provincial level are gathered from Indonesia Statistic Bureau or Badan Pusat Statistik (BPS). Rural banks and Islamic banks are not considered due to their particular characteristics (Nys et al., 2015) ${ }^{3}$. Our dependent variable is income inequality measured by the Gini Index expressed in percentage terms. The explanatory variables of interest are the different types of bank loans. We differentiate loans into three types and use as a scale factor each the population in each province. As alternative proxies, we include loan growth and its standard deviation (loan volatility) from January to December of each year. The different categories of loans are defined as follows:

1. Loan to Micro, Small, and Medium Enterprises (Loan to MSMEs)

We scale this variable by population. The criteria of MSMEs are based on Indonesia Act. Number 20/2008 regarding micro, small, medium enterprises. Micro enterprises are those with net assets of no more than 50 million IDR (about the equivalent of around 3700 USD) ${ }^{4}$, small enterprises are those with net assets of no more than 500 million IDR (around 37,000 USD), and medium enterprises are those with net assets of no more than 10 billion IDR (around 740,000 USD). Loan to MSMEs provide more benefits to people in the area, as one of its characteristics is that MSMEs tend to be labor intensive rather than capital intensive, we expect the coefficient associated to loan to MSMEs to be negative and significant.

2. Loan for Investment and Working Capital (Business Loans)

We here consider the total amount of loans granted by banks in each province for either investment or working capital to businesses which are not categorized as MSMEs during a one-year period. A working capital loan is a loan for day to day business operations while an investment loan is a loan for longer term purposes. A business loan, either working capital loan or investment loan, which tends to be more capitalintensive, is expected to only benefit shareholders or the management of relatively large

\footnotetext{
${ }^{3}$ Moreover, rural banks and islamic banks account for a relatively small share of total bank assets in Indonesia.

${ }^{4}$ Central Bank of Indonesia exchange rate as of October, 2015, 1 USD = 13,513 IDR
} 
companies. We hence expect the coefficients associated to such variables to be positive and significant.

3. Loan for consumption (Consumer loans)

We take the total amount of bank loans in each province for consumption purposes. Because such loans are generally not accessible to the poor, we expect the coefficient associated to this variable to be positive and significant.

Following the existing literature, we control for socioeconomic conditions that could impact inequality in Indonesia. It is widely argued that socioeconomic conditions could be reflected by unemployment, life expectancy, education and living standards (Trinugroho et al., 2015). For instance, Beck et al. (2010) include the unemployment rate and level of education as control variables in their regressions.

In our investigation, we consider the unemployment rate, education, and the Human Development Index-HDI. A higher unemployment rate is expected to be associated with a higher level of income inequality. Data on the unemployment rate in each province are provided by BPS.

Education as well as Human Development Index is proxies of human capital. Referring to UNDP, the Human Development Index (HDI) is defined as a summary measure of average achievement in key dimensions of human development: a long and healthy life, being educated having a decent standard of living. HDI is therefore expected to be negatively associated with income inequality. We consider the school enrollment ratio as a proxy of education. Education is also expected to be negatively related to income inequality. These data are provided by BPS.

We also control for other factors that may impact income inequality. We consider two macroeconomic indicators. First, the GDP growth rate since more rapid growth might help in alleviating inequality. Second, government expenditure to capture possible redistribution effects in favor of low-income groups (Kim and Lin, 2011). We measure government expenditure as the amount of government expenditure in a one-year period in a province scaled by its GDP (Gov. Expenditures). These two macroeconomic indicators are provided by BPS.

In Indonesia, there has been unequal infrastructure development among regions. The most developed region is Java and other western Indonesian provinces, followed by Central Indonesia, and Eastern Indonesia. To take into account this development disparity we use dummy variables indicating the three Indonesian regions, which are Western Indonesia (WEST), Central Indonesia (CENTRAL), and Eastern Indonesia (EAST).

\section{Hypothesis Testing and Model Specification}

To test our hypothesis, whether different types of loans impact income inequality differently, we use the following specification.

$$
\text { Gini }_{p, t}=\alpha+\beta_{1} \text { Lending }_{p, t}+\text { Control Variables }+\varepsilon_{p, t} \ldots \text { (1) }
$$

We use Random Effect estimation. We conduct Hausman tests to choose between fixed effects versus random effects. The result shows that there is no significant difference 
between the two models (with p-value>0.1), thus random effects are preferable to run our regression ${ }^{5}$.

\section{Results}

\subsection{Descriptive statistics and correlation matrix}

Table 1 shows descriptive statistics of our sample consisting of 33 provinces from 2007 to 2013 and table 2 the correlation matrix which shows that four types of loans which are Loan working capital (business loans), Loan for Investment (business loans), Loan to MSMEs, Loan for Consumption (consumer loans) are strongly correlated. Consequently, we separately introduce each loan type in the regressions.

\section{Table 1. General descriptive statistics}

\begin{tabular}{lrrrrrrrr} 
Stats. & $\mathrm{N}$ & $\mathrm{mean}$ & $\mathrm{sd}$ & $\mathrm{min}$ & $\mathrm{p} 25$ & $\mathrm{p} 50$ & $\mathrm{p} 75$ & $\max$ \\
\hline Gini & 231 & 0.354 & 0.042 & 0.259 & 0.326 & 0.35 & 0.38 & 0.46 \\
Loan Work. Cap. & 231 & 35.714 & 98.327 & 2.417 & 10.042 & 15.912 & 26.448 & 957.557 \\
Loan Investment & 231 & 16.757 & 51.301 & 0.278 & 2.970 & 5.340 & 11.580 & 520.411 \\
Loan MSME & 231 & 29.023 & 26.772 & 6.030 & 16.792 & 22.946 & 31.762 & 260.206 \\
Loan Consumption & 231 & 26.953 & 40.044 & 3.789 & 10.866 & 17.890 & 28.766 & 353.880 \\
Gr Loan Work. Cap. & 231 & 21.792 & 34.941 & -455 & 18 & 24 & 31 & 82 \\
Gr Loan Investment & 231 & 16.442 & 70.982 & -1004 & 14 & 23 & 30 & 97 \\
Gr Loan SME & 231 & 22.329 & 20.261 & -161 & 18 & 23 & 29 & 100 \\
Gr Loan Consumption & 231 & 15.095 & 47.131 & -669 & 14 & 18 & 23 & 92 \\
HDI & 231 & 71.790 & 3.673 & 42.7 & 70 & 71.94 & 74.11 & 79 \\
Gov. Expenditures & 231 & 2.678 & 1.721 & 0.58 & 1.602 & 2.277 & 3.259 & 11.268 \\
Unemployment rate & 231 & 6.570 & 2.766 & 1.79 & 4.51 & 6 & 8.37 & 15.75 \\
GDP growth & 231 & 6.253 & 3.445 & -5.51 & 5.29 & 6.11 & 7.16 & 28.47 \\
Education & 231 & 65.230 & 4.974 & 51.3894 & 61.7525 & 65.1925 & 67.9479 & 81.0064 \\
Population (in thousands) & 231 & 7,201 & 10,200 & 760 & 2,212 & 3,627 & 7,450 & 43,100 \\
\hline
\end{tabular}

Gini = gini index; Loan Work. Cap. = 1000*Bank loan for working capital on third party/population; Loan Investment $=1000 *$ Bank loan for investment on third party/population; Loan MSME $=1000 *$ Bank loan for investment and working capital on micor, small, and medium enterprises (MSME)/population; Loan Consumption = 1000*Bank loan for consumption/population; Gr Work. Cap. = growth of bank loan for working capital in period t (from January to December); Gr Loan Investment $=$ growth of bank loan for investment capital in period $t$ (from January to December); Gr Loan MSME = growth of bank loan for MSME in period t (from January to December); Gr Loan Consumption = growth of bank loan for consumption in period $t$ (from January to December); HDI=Human Development Index; Gov. Expenditures $=1000 *$ government expenditure/GDP; Unemployment rate $=$ unemployment rate in a province; GDP Growth=province's annual GDP growth; Education=education index; Population=number of population in a province.

\footnotetext{
${ }^{5}$ Endogeneity could be a concern with possibly two main sources. The first is simultaneity. Regarding our variable of concern, income inequality (Gini index) and bank loan, we do not suspect any simultaneous relationship between the two. We hypothesize that loan influences income inequality and not the other way around. Thus, it is unlikely that the relationship between income inequality and bank loan could be bidirectional. The second source of endogeneity is the omitted variable bias, a variable which could be correlated with independent variables. In our specification, we include all the variables that are expected to affect the Gini index. Furthermore, we also run fixed effect regressions which provide similar results but because both the Hausman test and the robust Hausman test favor random effects we run our regressions using such estimation techniques.
} 


\subsection{Empirical results}

Table 3 presents the results of random effect panel data regressions where the dependent variable is the Gini Index. The results show that Loan to MSMEs has a significant and negative impact on income inequality. However, Business loans which is decomposed as working capital and investment have both a significant but positive impact on income inequality. Consumer loans (Consumption) and the growth of such loans also positively and significantly affect income inequality. Regarding macroeconomic and socioeconomic conditions, only government expenditure has a significant and negative relationship with income inequality. Higher government expenditure (scaled by GDP) in a province is associated with lower income inequality. Turning to our dummy variable which controls for development disparity across regions, the result shows that the eastern part of Indonesia experiences larger income inequality than other parts of Indonesia.

Our results provide evidence that bank lending is significantly associated with income inequality. First, loans to micro, small, and medium enterprise could help to reduce income inequality. Because MSMEs tend to be labor intensive, the expansion is expected to stimulate job creation lead to lower unemployment. Second, we find evidence that business loans to large firms (either working capital or investment loan) are positively associated with the Gini index and thus exacerbate income inequality. As micro, small, medium-sized enterprise, large companies or firms also need loans to expand their business .Nevertheless, these types of loans are essentially beneficial for the rich who own or manage such large firms. Third, likewise, consumer loans are also found to be positively associated with the Gini index. As long as consumer loan regulation in Indonesia remains focused on assessing the borrower's social background access to such loans will not be beneficial for the poor. To grant consumer loans to individuals or households, banks take into account several socioeconomic dimensions: level of capital or wealth, collateral, income level, and social background. Such requirements can generally only be met by middle upper class individuals or households.

Regarding control variables, government expenditure has a significant negative effect on income inequality. This result is consistent with the existence of poverty alleviation programs in each province aimed at improving life by redistributing tax revenues. For dummy variables, we find that the eastern side of Indonesia suffers from greater income inequality which is also consistent with the relatively difficult position of this part of Indonesia in terms of access to infrastructure, education and health development compared to the rest of the archipelago. 
Table 2. Correlation Matrix between independent variables

\begin{tabular}{|c|c|c|c|c|c|c|c|c|c|c|c|c|c|c|}
\hline & 1 & 2 & 3 & 4 & 5 & 6 & 7 & 8 & 9 & 10 & 11 & 12 & 13 & 14 \\
\hline 1 Loan Work. Cap. & 1 & & & & & & & & & & & & & \\
\hline 2 Loan Investment & $0.994 *$ & 1 & & & & & & & & & & & & \\
\hline 3 Loan MSME & $0.726^{*}$ & $0.711^{*}$ & 1 & & & & & & & & & & & \\
\hline 4 Loan Consumption & $0.968 *$ & $0.966^{*}$ & $0.764 *$ & 1 & & & & & & & & & & \\
\hline 5 Gr Loan Work. Cap. & -0.0358 & -0.0342 & -0.00925 & -0.0416 & 1 & & & & & & & & & \\
\hline 6 Gr Loan Investment & 0.0151 & 0.0156 & 0.0362 & 0.0266 & $0.931^{*}$ & 1 & & & & & & & & \\
\hline 7 Gr Loan SME & -0.107 & -0.112 & -0.0766 & $-0.131^{*}$ & $0.180^{*}$ & 0.119 & 1 & & & & & & & \\
\hline 8 Gr Loan Consumption & -0.00876 & -0.00905 & 0.0129 & -0.00451 & $0.944 *$ & $0.963 *$ & $0.157 *$ & 1 & & & & & & \\
\hline $9 \mathrm{HDI}$ & $0.332 *$ & $0.343^{*}$ & $0.412 *$ & $0.376^{*}$ & -0.0527 & 0.00467 & -0.0970 & -0.0211 & 1 & & & & & \\
\hline 10 Gov. Expenditures & 0.0604 & 0.0772 & 0.0568 & $0.131 *$ & 0.0394 & 0.0478 & 0.0780 & 0.0292 & -0.0984 & 1 & & & & \\
\hline 11 Unemployment rate & $0.234 *$ & $0.218^{*}$ & $0.298^{*}$ & $0.205^{*}$ & 0.0229 & -0.00147 & -0.0383 & 0.0160 & 0.118 & $-0.231^{*}$ & 1 & & & \\
\hline 12 Education & $0.147 *$ & $0.152^{*}$ & $0.157^{*}$ & $0.221 *$ & 0.0320 & 0.0930 & -0.0662 & 0.0609 & $0.395^{*}$ & -0.0218 & 0.0564 & 1 & & \\
\hline 13 GDP growth & 0.00858 & -0.00700 & -0.00193 & 0.0236 & 0.0208 & 0.0172 & 0.0431 & 0.0319 & -0.00768 & $0.337 *$ & -0.0884 & -0.105 & 1 & \\
\hline 14 Log Population & 0.0526 & 0.0247 & -0.0146 & -0.0179 & 0.00878 & 0.0355 & -0.0415 & 0.0152 & 0.0761 & $-0.401 *$ & $0.234 *$ & -0.108 & -0.0657 & 1 \\
\hline
\end{tabular}

Gini = gini index; Loan Work. Cap. = 1000*Bank loan for working capital on third party/population; Loan Investment = 1000*Bank loan for investment on third party/population; Loan MSME $=$ 1000*Bank loan for investment and working capital on micro, small, and medium enterprises (MSME)/population; Loan Consumption = 1000*Bank loan for consumption/population; Gr Work. Cap. = growth of bank loan for working capital in period t (from January to December); Gr Loan Investment = growth of bank loan for investment capital in period $t$ (from January to December); Gr Loan $\mathrm{MSME}$ = growth of bank loan for MSME in period $\mathrm{t}$ (from January to December); Gr Loan Consumption = growth of bank loan for consumption in period $\mathrm{t}$ (from January to December); HDI=Human Development Index; Gov. Expenditures=1000*government expenditure/GDP; GDP Growth=province's annual GDP growth; Unemployment=unemployment rate; Education= education index; Log Population $=\log$ of population by province. ${ }^{*} \mathrm{p}<0.05$. 
Table 3. Regression types of bank loans on income inequality

\begin{tabular}{|c|c|c|c|c|c|c|c|c|c|c|c|c|c|}
\hline \multirow{3}{*}{$\begin{array}{l}\text { Dependent: } \\
\text { Gini }\end{array}$} & \multicolumn{13}{|c|}{ RE } \\
\hline & \multirow[t]{2}{*}{ Business } & \multicolumn{3}{|c|}{ Work. Cap. } & \multicolumn{3}{|c|}{ Investment } & \multicolumn{3}{|c|}{ MSME } & \multicolumn{3}{|c|}{ Consumption } \\
\hline & & 1 & 2 & 3 & 4 & 5 & 6 & 7 & 8 & 9 & 10 & 11 & 12 \\
\hline LOAN & $\begin{array}{l}0.0000439 * * * \\
(5.65)\end{array}$ & $\begin{array}{l}0.000069 * * * \\
(5.86)\end{array}$ & & & $\begin{array}{l}0.000116^{* * *} \\
(4.93)\end{array}$ & & & $\begin{array}{l}-0.000199 * * \\
(-2.20)\end{array}$ & & & $\begin{array}{l}0.000214 * * * \\
(3.44)\end{array}$ & & \\
\hline Loan Growth & & & $\begin{array}{l}0.0000215 \\
(1.43)\end{array}$ & & & $\begin{array}{l}0.0000189 * \\
(1.65)\end{array}$ & & & $\begin{array}{l}-0.0000846 \\
(-1.39)\end{array}$ & & & $\begin{array}{l}0.0000248 * * \\
(2.07)\end{array}$ & \\
\hline Loan Volatility & & & & $\begin{array}{l}4.54 \mathrm{e}-08 \\
(1.38)\end{array}$ & & & $\begin{array}{l}-0.000000536 \\
(-0.88)\end{array}$ & & & $\begin{array}{l}-0.000000344 \\
(-1.01)\end{array}$ & & & $\begin{array}{l}0.000000173 \\
(1.41)\end{array}$ \\
\hline HDI & $\begin{array}{l}-0.000331 \\
(-0.88)\end{array}$ & $\begin{array}{l}-0.000332 \\
(-0.88)\end{array}$ & $\begin{array}{l}-0.000235 \\
(-0.65)\end{array}$ & $\begin{array}{l}-0.000235 \\
(-0.65)\end{array}$ & $\begin{array}{l}-0.000329 \\
(-0.87)\end{array}$ & $\begin{array}{l}-0.000251 \\
(-0.68)\end{array}$ & $\begin{array}{l}-0.000217 \\
(-0.62)\end{array}$ & $\begin{array}{l}-0.000145 \\
(-0.43)\end{array}$ & $\begin{array}{l}-0.000202 \\
(-0.59)\end{array}$ & $\begin{array}{l}-0.000229 \\
(-0.64)\end{array}$ & $\begin{array}{l}-0.000347 \\
(-0.89)\end{array}$ & $\begin{array}{l}-0.000233 \\
(-0.65)\end{array}$ & $\begin{array}{l}-0.000232 \\
(-0.64)\end{array}$ \\
\hline Gov. Expenditure & $\begin{array}{l}-0.000555^{* *} \\
(-2.10)\end{array}$ & $\begin{array}{l}-0.000555^{* * *} \\
(-2.11)\end{array}$ & $\begin{array}{l}-0.000621^{* *} \\
(-2.38)\end{array}$ & $\begin{array}{l}-0.000614 * * \\
(-2.35)\end{array}$ & $\begin{array}{l}-0.000557 * * \\
(-2.09)\end{array}$ & $\begin{array}{l}-0.000616^{* *} \\
(-2.38)\end{array}$ & $\begin{array}{l}-0.000615^{* * *} \\
(-2.32)\end{array}$ & $\begin{array}{l}-0.000652 * * \\
(-2.42)\end{array}$ & $\begin{array}{l}-0.000617^{* *} * \\
(-2.33)\end{array}$ & $\begin{array}{l}-0.000616^{* * *} \\
(-2.34)\end{array}$ & $\begin{array}{l}-0.000527 * * \\
(-2.01)\end{array}$ & $\begin{array}{l}-0.000619 * * \\
(-2.40)\end{array}$ & $\begin{array}{l}-0.000611^{* *} \\
(-2.33)\end{array}$ \\
\hline Log Population & $\begin{array}{l}0.00482 \\
(0.74)\end{array}$ & $\begin{array}{l}0.00478 \\
(0.73)\end{array}$ & $\begin{array}{l}0.00431 \\
(0.64)\end{array}$ & $\begin{array}{l}0.00428 \\
(0.64)\end{array}$ & $\begin{array}{l}0.00489 \\
(0.75)\end{array}$ & $\begin{array}{l}0.00425 \\
(0.64)\end{array}$ & $\begin{array}{l}0.00599 \\
(0.81)\end{array}$ & $\begin{array}{l}0.00365 \\
(0.54)\end{array}$ & $\begin{array}{l}0.00444 \\
(0.66)\end{array}$ & $\begin{array}{l}0.00483 \\
(0.71)\end{array}$ & $\begin{array}{l}0.00578 \\
(0.90)\end{array}$ & $\begin{array}{l}0.00428 \\
(0.64)\end{array}$ & $\begin{array}{l}0.00412 \\
(0.62)\end{array}$ \\
\hline GDP Growth & $\begin{array}{l}0.000352 \\
(0.67)\end{array}$ & $\begin{array}{l}0.000346 \\
(0.66)\end{array}$ & $\begin{array}{l}0.000306 \\
(0.57)\end{array}$ & $\begin{array}{l}0.000296 \\
(0.56)\end{array}$ & $\begin{array}{l}0.000362 \\
(0.68)\end{array}$ & $\begin{array}{l}0.000317 \\
(0.58)\end{array}$ & $\begin{array}{l}0.000307 \\
(0.57)\end{array}$ & $\begin{array}{l}0.000238 \\
(0.46)\end{array}$ & $\begin{array}{l}0.000316 \\
(0.60)\end{array}$ & $\begin{array}{l}0.000305 \\
(0.57)\end{array}$ & $\begin{array}{l}0.000376 \\
(0.71)\end{array}$ & $\begin{array}{l}0.000301 \\
(0.56)\end{array}$ & $\begin{array}{l}0.000294 \\
(0.55)\end{array}$ \\
\hline Unemployment & $\begin{array}{l}-0.00177 \\
(-1.10)\end{array}$ & $\begin{array}{l}-0.00180 \\
(-1.11)\end{array}$ & $\begin{array}{l}-0.00160 \\
(-1.01)\end{array}$ & $\begin{array}{l}-0.00165 \\
(-1.04)\end{array}$ & $\begin{array}{l}-0.00171 \\
(-1.07)\end{array}$ & $\begin{array}{l}-0.00158 \\
(-1.00)\end{array}$ & $\begin{array}{l}-0.00155 \\
(-0.96)\end{array}$ & $\begin{array}{l}-0.00125 \\
(-0.77)\end{array}$ & $\begin{array}{l}-0.00155 \\
(-1.00)\end{array}$ & $\begin{array}{l}-0.00161 \\
(-1.01)\end{array}$ & $\begin{array}{l}-0.00193 \\
(-1.19)\end{array}$ & $\begin{array}{l}-0.00160 \\
(-1.01)\end{array}$ & $\begin{array}{l}-0.00165 \\
(-1.03)\end{array}$ \\
\hline Education & $\begin{array}{l}-0.000723 \\
(-0.64)\end{array}$ & $\begin{array}{l}-0.000728 \\
(-0.64)\end{array}$ & $\begin{array}{l}-0.000899 \\
(-0.77)\end{array}$ & $\begin{array}{l}-0.000881 \\
(-0.76)\end{array}$ & $\begin{array}{l}-0.000719 \\
(-0.63)\end{array}$ & $\begin{array}{l}-0.000870 \\
(-0.75)\end{array}$ & $\begin{array}{l}-0.000892 \\
(-0.76)\end{array}$ & $\begin{array}{l}-0.000796 \\
(-0.70)\end{array}$ & $\begin{array}{l}-0.000914 \\
(-0.78)\end{array}$ & $\begin{array}{l}-0.000903 \\
(-0.77)\end{array}$ & $\begin{array}{l}-0.000742 \\
(-0.66)\end{array}$ & $\begin{array}{l}-0.000887 \\
(-0.76)\end{array}$ & $\begin{array}{l}-0.000865 \\
(-0.75)\end{array}$ \\
\hline 'CENTRAL & $\begin{array}{l}0.0121 \\
(0.94)\end{array}$ & $\begin{array}{l}0.0123 \\
(0.95)\end{array}$ & $\begin{array}{l}0.00978 \\
(0.74)\end{array}$ & $\begin{array}{l}0.0102 \\
(0.77)\end{array}$ & $\begin{array}{l}0.0117 \\
(0.91)\end{array}$ & $\begin{array}{l}0.00968 \\
(0.74)\end{array}$ & $\begin{array}{l}0.00879 \\
(0.65)\end{array}$ & $\begin{array}{l}0.00877 \\
(0.65)\end{array}$ & $\begin{array}{l}0.0102 \\
(0.76)\end{array}$ & $\begin{array}{l}0.00964 \\
(0.72)\end{array}$ & $\begin{array}{l}0.0126 \\
(0.99)\end{array}$ & $\begin{array}{l}0.00968 \\
(0.73)\end{array}$ & $\begin{array}{l}0.0103 \\
(0.79)\end{array}$ \\
\hline EAST & $\begin{array}{l}0.0606 * * * \\
(2.66)\end{array}$ & $\begin{array}{l}0.0606^{* * * *} \\
(2.67)\end{array}$ & $\begin{array}{l}0.0611^{* * * *} \\
(2.64)\end{array}$ & $\begin{array}{l}0.0613 \text { *** } \\
(2.65)\end{array}$ & $\begin{array}{l}0.0605 * * * \\
(2.65)\end{array}$ & $\begin{array}{l}0.0606^{* * * *} \\
(2.63)\end{array}$ & $\begin{array}{l}0.0605^{* *} \\
(2.57)\end{array}$ & $\begin{array}{l}0.0603 * * \\
(2.54)\end{array}$ & $\begin{array}{l}0.0621 * * * \\
(2.69)\end{array}$ & $\begin{array}{l}0.0610 \text { *** } \\
(2.62)\end{array}$ & $\begin{array}{l}0.0602 * * * \\
(2.67)\end{array}$ & $\begin{array}{l}0.0610^{* * * *} \\
(2.64)\end{array}$ & $\begin{array}{l}0.0613 \text { *** } \\
(2.65)\end{array}$ \\
\hline Constant & $\begin{array}{l}0.341^{* *} \\
(2.26) \\
\end{array}$ & $\begin{array}{l}0.342^{* * *} \\
(2.27) \\
\end{array}$ & $\begin{array}{l}0.356^{* * *} \\
(2.29) \\
\end{array}$ & $\begin{array}{l}0.355^{* *} \\
(2.28) \\
\end{array}$ & $\begin{array}{l}0.339 * * \\
(2.26) \\
\end{array}$ & $\begin{array}{l}0.356^{* *} \\
(2.31) \\
\end{array}$ & $\begin{array}{l}0.330^{* * *} \\
(2.01) \\
\end{array}$ & $\begin{array}{l}0.356 \text { ** } \\
(2.27) \\
\end{array}$ & $\begin{array}{l}0.353^{* *} \\
(2.27) \\
\end{array}$ & $\begin{array}{l}0.349^{* * *} \\
(2.22) \\
\end{array}$ & $\begin{array}{l}0.327^{* * *} \\
(2.23) \\
\end{array}$ & $\begin{array}{l}0.355^{* * *} \\
(2.31) \\
\end{array}$ & $\begin{array}{l}0.356^{* * *} \\
(2.30) \\
\end{array}$ \\
\hline Year Fixed Effects & Yes & Yes & Yes & Yes & Yes & Yes & Yes & Yes & Yes & Yes & Yes & Yes & Yes \\
\hline No. Observations & 231 & 231 & 231 & 231 & 231 & 231 & 231 & 231 & 231 & 231 & 231 & 231 & 231 \\
\hline No. Province & 33 & 33 & 33 & 33 & 33 & 33 & 33 & 33 & 33 & 33 & 33 & 33 & 33 \\
\hline R-squared & 0.420 & 0.42 & 0.4 & 0.397 & 0.42 & 0.4 & 0.390 & 0.37 & 0.4 & 0.394 & 0.43 & 0.4 & 0.399 \\
\hline
\end{tabular}

Gini = gini index; LOAN: Work. Cap. = 1000*Bank loan for working capital on third party/population; Investment = 1000*Bank loan for investment on third party/population; MSME = 1000*Bank loan for investment and working capital on MSMEs/population; Consumption = 1000*Bank loan for consumption/population; LOAN growth: Work. Cap. = growth of bank loan for working capital in period $\mathrm{t}$ (from January to December); Investment = growth of bank loan for investment capital in period $\mathrm{t}$ (from January to December); MSME = growth of bank loan for MSME in period $\mathrm{t}$ (from January to December); Consumption = growth of bank loan for consumption in period $\mathrm{t}$ (from January to December); Loan Volatility = standard deviation each loans from january to december in a period; HDI=Human Development Index; Gov. Expenditures=1000* government expenditure/GDP; Log Population=log of population by province; GDP Growth=province's annual GDP growth ; Unemployment=unemployment rate; Education= education index; CENTRAL=dummy variable for provinces in Central Indonesia; EAST=dummy variable for provinces in East Indonesia. t-statistic in parentheses. *** $\mathrm{p}<0.01 * * \mathrm{p}<0.05,{ }^{*} \mathrm{p}<0.1$ 


\section{Conclusion}

In this paper we investigate whether financial development affects income inequality in a single country by considering data with a detailed breakdown on lending. Our study covers 33 Indonesian provinces over the 2007-2013 period and focuses on the Gini index.

Our findings show that bank lending has a significant impact on income inequality in Indonesia, but the relationship is not clear-cut. Loans to micro, small and medium-sized enterprises contribute to significantly reduce income inequality but business loans to larger firms (either working capital or investment loans) and consumer loans significantly increase inequality. Our findings have some noteworthy policy implications. First, regulation could bolster banks to channel more loans to micro, small, medium-sized enterprises to stimulate job creation. Second, regulators should consider reforming consumer loan regulation to make bank loans accessible to a larger part of the population and not only to the middle upper class. In order to give more access to finance, regulators should make banking development pro-poor. Moreover, there should be equal financial development across provinces to facilitate access to finance all over the regions.

\section{References}

Banerjee, A.V. and A.F. Newman. 1993. Occupational Choice and the Process of Development. The Journal of Political Economy, 101 (2), 274-298.

Beck, T., Demirguc-kunt, A., and Levine, R. 2007. Finance, inequality, and the poor. Journal of Economic Growth, 12(1), 27-49.

Beck, T., Levine, R., and Levkov., A. 2010.Big bad banks? The winners and losers from bank deregulation in the United States. The Journal of Finance, 65(5), 1637-1667.

Beck, T., Levine, R., and Loayza, N. 2000. Finance and the source of growth. Journal of Financial Economics, 58,195-209.

Clarke, G.R.G., L.C. Xu, and H. Zou. 2003. Finance and Income Inequality: Test of Alternative Theories?. World Bank Policy Research Working Paper, wp 2984, World Bank, Washington D.C.

Clarke, G. R., Xu, L. C., and Zou, H. F. 2006. Finance and income inequality: what do the data tell us?. Sourthern Economic Journal. 578-596.

Galor, O. and J. Zeira. 1993. Income Distribution and Macroeconomics. The Review of Economic Studies, 60(1), 35-52.

Gimet, C. and Lagoarde-Segot, T. 2011. A closer look at financial development and income distribution. Journal of Banking and Finance, 35, 1698-1713. 
Greenwood, J. and B. Jovanovic. 1990. Financial Development, Growth, and the Distribution of Income. Journal of Political Economy, 98 (5), 1076 - 1107.

Kappel, V. 2010. The effect of financial development on income inequality and poverty. CERETH Center of Economics Research ETH Zurich Working Paper.

Kim, D. H. and Lin, S. C. 2011. Nonlinearity in the financial development-income inequality nexus. Journal of Comparative Economics, 39, 310-325.

Levine, R. 2005. Finance and growth: Theory and evidence. Handbook of Economic Growth Vol. 1 , chapter 12, pp. 865-934

Li, H., L. Squire, and H. Zou. 1998. Explaining International and Intertemporal Variations in Income Distribution. The Economic Journal, 108 (January), 26-43.

Liang, Z. 2006. Financial Development and Income Distribution: A System Panel Analysis with Application to Urban China. Journal of Economic Development, 31 (2), 1-21.

Trinugroho, I., Agusman A., Tarazi, A., 2014. Why have bank interest margins been so high in Indonesia since the 1997/1998 financial crisis? Research in International Business and Finance 32, pp. 139-158.

Trinugroho I., Agusman A., Ariefianto M. D., Darsono D., Tarazi A., 2015. Determinants of cross regional disparity in financial deepening : Evidence from Indonesian provinces. Economics Bulletin, Vol. 35, Issue 2, pp. 896-910 